\title{
Review \\ Copper as a Collaborative Partner of Zinc-Induced Neurotoxicity in the Pathogenesis of Vascular Dementia
}

\author{
Masahiro Kawahara*(D), Ken-ichiro Tanaka and Midori Kato-Negishi \\ Department of Bio-Analytical Chemistry, Faculty of Pharmacy, Research Institute of Pharmaceutical Sciences, \\ Musashino University, Tokyo 202-8585, Japan; k-tana@musashino-u.ac.jp (K.-i.T.); \\ mnegishi@musashino-u.ac.jp (M.K.-N.) \\ * Correspondence: makawa@musashino-u.ac.jp; Tel./Fax: +81-42-468-8299
}

Citation: Kawahara, M.; Tanaka, K.-i.; Kato-Negishi, M. Copper as a Collaborative Partner of

Zinc-Induced Neurotoxicity in the Pathogenesis of Vascular Dementia. Int. J. Mol. Sci. 2021, 22, 7242. https://doi.org/10.3390/ijms 22147242

Academic Editor: Wolfgang Linert

Received: 30 May 2021

Accepted: 29 June 2021

Published: 6 July 2021

Publisher's Note: MDPI stays neutral with regard to jurisdictional claims in published maps and institutional affiliations.

Copyright: (c) 2021 by the authors. Licensee MDPI, Basel, Switzerland This article is an open access article distributed under the terms and conditions of the Creative Commons Attribution (CC BY) license (https:// creativecommons.org/licenses/by/ $4.0 /)$.

\begin{abstract}
Copper is an essential trace element and possesses critical roles in various brain functions. A considerable amount of copper accumulates in the synapse and is secreted in neuronal firings in a manner similar to zinc. Synaptic copper and zinc modulate neuronal transmission and contribute to information processing. It has been established that excess zinc secreted during transient global ischemia plays central roles in ischemia-induced neuronal death and the pathogenesis of vascular dementia. We found that a low concentration of copper exacerbates zinc-induced neurotoxicity, and we have demonstrated the involvement of the endoplasmic reticulum (ER) stress pathway, the stress-activated protein kinases/c-Jun amino-terminal kinases (SAPK/JNK) signaling pathway, and copper-induced reactive oxygen species (ROS) production. On the basis of our results and other studies, we discuss the collaborative roles of copper in zinc-induced neurotoxicity in the synapse and the contribution of copper to the pathogenesis of vascular dementia.
\end{abstract}

Keywords: zinc; endoplasmic reticulum; MAP kinase; calcium homeostasis; mitochondria; synapse

\section{Introduction}

Copper $(\mathrm{Cu})$ is the third most abundant trace element in the brain. $\mathrm{Cu}$ is essential for most life forms and plays crucial roles in various biological functions, including electron transport, oxygen transport and aerobic respiration [1]. Despite its significance, excess free $\mathrm{Cu}$ is toxic because $\mathrm{Cu}$ produces reactive oxygen species (ROS) in the redox activity between $\mathrm{Cu}^{2+}$ and $\mathrm{Cu}^{+}$. Increasing evidence has suggested that the dyshomeostasis of $\mathrm{Cu}$ is implicated in the pathogenesis of various neurodegenerative diseases, such as Alzheimer's disease (AD), prion diseases, Parkinson's disease (PD), dementia with Lewy bodies (DLB), and amyotrophic lateral sclerosis (ALS) [2-5].

Here, we focus on the link between $\mathrm{Cu}$ and the pathogenesis of a vascular type of senile dementia (VD). VD mainly occurs after stroke or ischemia. During transient global ischemia, the deprivation of glucose and oxygen by the disruption of blood flow and the subsequent neuronal excitation causes a sustainable release of glutamate, which causes neurodegeneration and leads to the pathogenesis of VD [6]. It is widely established that excess zinc $(\mathrm{Zn})$ co-released with glutamate plays central roles in ischemia-induced neurodegeneration and the pathogenesis of VD [7]. Copper ions $\left(\mathrm{Cu}^{2+}\right)$ and zinc ions $\left(\mathrm{Zn}^{2+}\right)$ share similar chemical characteristics and bind the same regions of chelators or metal-binding proteins. Therefore, $\mathrm{Cu}^{2+}$ acts competitively with $\mathrm{Zn}^{2+}$ in several biological functions. The intake of excess $\mathrm{Zn}$ causes a $\mathrm{Cu}$ deficiency and vice versa [8]. However, we found that the co-existence of a low concentration of $\mathrm{Cu}^{2+}$ markedly exacerbated $\mathrm{Zn}^{2+}$ induced neuronal death [9]. We have investigated the molecular pathways implicated in $\mathrm{Cu}^{2+}$-enhanced $\mathrm{Zn}^{2+}$-induced neurotoxicity and demonstrated the involvement of the endoplasmic reticulum (ER) stress pathway and the stress-activated protein kinases/c-Jun amino-terminal kinases (SAPK/JNK) signaling pathway $[9,10]$. We also demonstrated that $\mathrm{Cu}^{2+}$-induced ROS may be an upstream factor of the ER stress pathway and the SAPK/JNK 
pathway in the neurodegeneration processes [11,12]. Considering that $\mathrm{Cu}^{2+}$ and $\mathrm{Zn}^{2+}$ coexist in the synaptic cleft under ischemic conditions, we hypothesize the involvement of $\mathrm{Cu}^{2+}$ as a collaborative partner of $\mathrm{Zn}^{2+}$-induced neurotoxicity and subsequent pathogenesis of VD. We also discuss the roles of $\mathrm{Cu}$-binding, amyloidogenic proteins in the synapse in the regulation of $\mathrm{Cu}$ homeostasis.

\section{Copper in the Brain}

$\mathrm{Cu}$ is an essential trace element and abundantly exists in the liver, kidney and brain [1]. Orally digested $\mathrm{Cu}$ is absorbed from the gastrointestinal pathway by divalent cation transporter 1 (DMT1) as $\mathrm{Cu}^{2+}$ or by copper transporter 1 (CTR1) as $\mathrm{Cu}^{+}$. Cu binds to ceruloplasmin and is then transported in the blood system. The copper-transporting ATPases (ATP7A and ATP7B) play essential roles in $\mathrm{Cu}$ distribution in the organs. $\mathrm{Cu}$ deficiency or excess due to the impairment of $\mathrm{Cu}$ transporters leads to severe neurodegenerative diseases, such as Menkes disease or Wilson's disease [13]. In the brain, Cu especially exists in the thalamus, substantia nigra, striatum, and hippocampus. Cu plays essential functions in the brain in the synthesis of neurotransmitters, myelination, and neuroprotection against ROS as a cofactor of various enzymes and functional proteins, including cytochrome $\mathrm{C}$ oxidase, lysyl oxidase, uricase, dopamine hydroxylase, tyrosinase and $\mathrm{Cu} / \mathrm{Zn}$ superoxide dismutase $(\mathrm{Cu} / \mathrm{Zn} \mathrm{SOD}) . \mathrm{Cu}$ is also involved in iron $(\mathrm{Fe})$ homeostasis because ceruloplasmin is a ferroxidase, which converts $\mathrm{Fe}^{2+}$ to $\mathrm{Fe}^{3+}$.

Increasing evidence suggests that $\mathrm{Cu}$ is involved in neurotransmission and information processing in the brain $[14,15]$. Although the majority of $\mathrm{Cu}$ rigidly binds to proteins, a substantial fraction of $\mathrm{Cu}$ is in the form of free $\mathrm{Cu}\left(\mathrm{Cu}^{2+}\right)$ or loosely bound to small molecular compounds in synaptic vesicles of neurons and is released into the synaptic clefts during neuronal excitation. Secreted $\mathrm{Cu}^{2+}$ regulates overall brain excitability by binding to several neurotransmitter receptors, including $N$-methyl-D-aspartate (NMDA)-type glutamate receptors, $\alpha$-amino-3-hydroxy-5-methylisoxazole-4-propionic acid (AMPA)-type glutamate receptors, $\gamma$-aminobutyric acid (GABA) receptors, and purinergic receptors. The accumulation of $\mathrm{Cu}$ in the brain reportedly altered GABA-mediated neurotransmission and promoted impulsive behaviors [16]. ATP7A plays a pivotal role in the transport of $\mathrm{Cu}$ into synaptic vesicles and, therefore, contributes to axon outgrowth and synaptogenesis [17].

It is well established that a considerable amount of $\mathrm{Zn}$ also accumulates in the presynaptic vesicles of glutamatergic neurons as free $\mathrm{Zn}\left(\mathrm{Zn}^{2+}\right)$ or in a loosely bound form [18] Synaptic $\mathrm{Zn}^{2+}$ is released with glutamate during neuronal excitation and binds to various neurotransmitter receptors, including NMDA-type glutamate receptors, AMPA receptors, and GABA receptors. These characteristics of $\mathrm{Zn}^{2+}$ are quite similar to those of $\mathrm{Cu}^{2+}$.

It is possible that-but has yet to be determined whether-secreted $\mathrm{Cu}^{2+}$ and $\mathrm{Zn}^{2+}$ can diffuse across the synaptic cleft, spill over to neighboring synapses, and modulate the activity of those neighboring synapses, as shown in Figure 1. Synaptic $\mathrm{Zn}^{2+}$ plays critical roles in information processing and memory formation $[19,20]$. It is plausible that differing concentrations of excitatory glutamate and inhibitory $\mathrm{Cu}^{2+}$ and $/$ or $\mathrm{Zn}^{2+}$ in adjacent synapses transmit spatio-temporal information about neuronal firings and facilitate the precise modulation of neuronal activity. This modulation of neuronal activity at adjacent synapses generates contrasting signals that may enable lateral inhibition and serve as the basis for synaptic plasticity [21]. Therefore, it is possible that "Cu signaling" and "Zn signaling" coordinate at the synapse and modulate the neuronal information [22,23]. Indeed, $\mathrm{Cu}$ deficiency caused impaired maturation of the hippocampus in immature rats [24].

Although the concentration of $\mathrm{Cu}$ and $\mathrm{Zn}$ in the cerebrospinal fluid (CSF) has been reported to be less than $1 \mu \mathrm{M}$ [25], the concentration in the synaptic cleft may be much higher compared with that in the CSF. The synaptic cleft is a small compartment conceptualized as a cylinder with a radius of $120 \mathrm{~nm}$ and a height of $20 \mathrm{~nm}$, and the total volume is estimated to be about $1 \%$ of the extracellular space [26]. Thus, it is possible that the concentrations of $\mathrm{Cu}^{2+}$ and $\mathrm{Zn}^{2+}$ are much higher compared with the CSF. Indeed, the 
concentration of glutamate in the synaptic cleft is estimated to reach the $\mathrm{mM}$ range after $1 \mathrm{~ms}$ of neuronal depolarization. Although the exact levels of $\mathrm{Zn}$ and $\mathrm{Cu}$ in the synaptic cleft remain controversial, the $\mathrm{Zn}$ concentrations are estimated to be 1-100 $\mu \mathrm{M}$ [27]. Kardos et al. found $\sim 100 \mu \mathrm{M}$ of $\mathrm{Cu}$ released into synaptic clefts by atomic absorption [28]. However, considering the chemical characteristics of $\mathrm{Cu}^{2+}$, it is plausible that synaptic $\mathrm{Cu}^{2+}$ loosely bound to small compounds such as organic acids and ATP. A study using a Cu-sensitive fluorescent probe demonstrated that $\sim 3 \mu \mathrm{M}$ of $\mathrm{Cu}$ is released in the synaptic clefts [29].

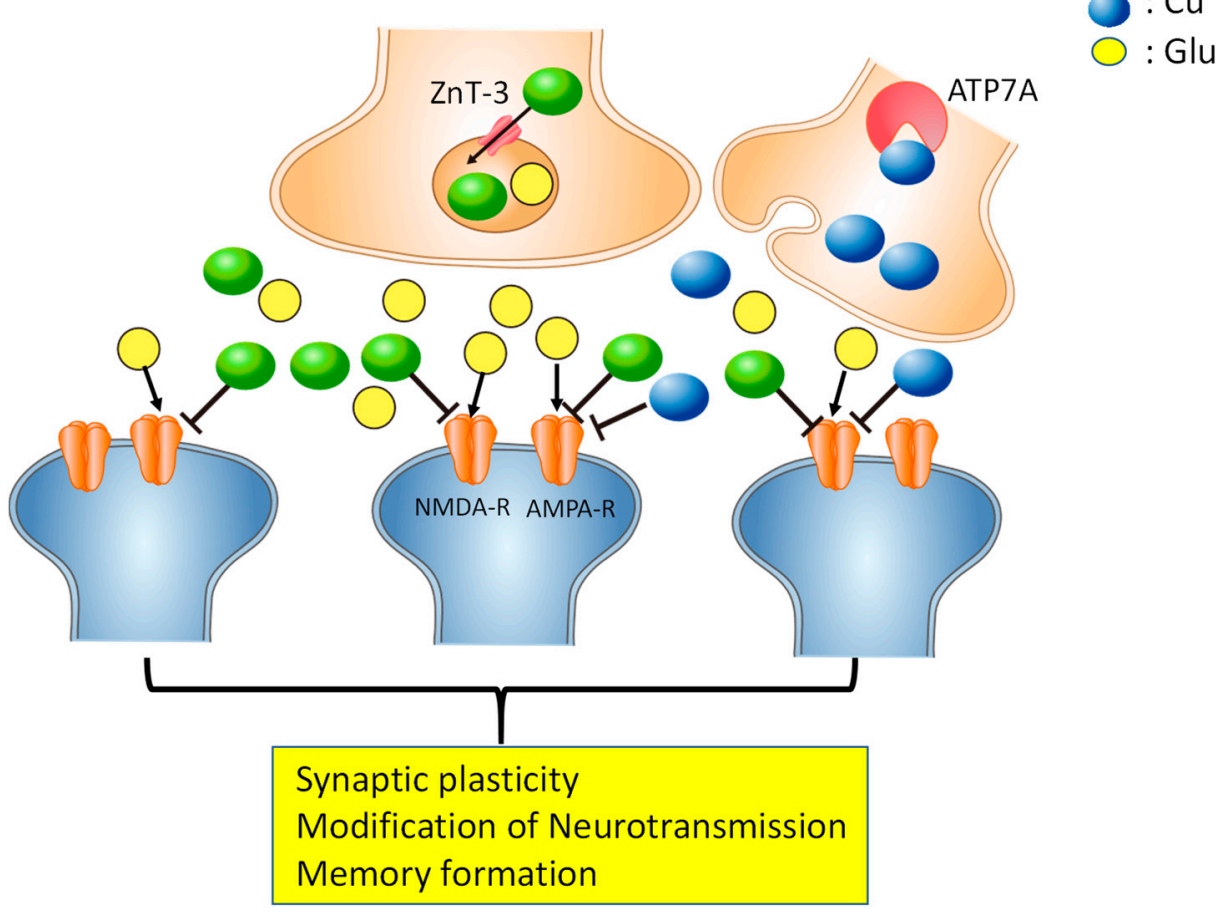

Figure 1. Copper and zinc in the synapse. Under normal conditions, $\mathrm{Cu}^{2+}$ and $\mathrm{Zn}^{2+}$ are stored in presynaptic vesicles, released with neurotransmitters such as glutamate, and bind to N-methyl-Daspartate (NMDA)-type glutamate receptors (NMDA-R), $\alpha$-amino-3-hydroxy-5-methylisoxazole4-propionic acid (AMPA)-type glutamate receptors (AMPA-R), or other receptors. ZnT-3, a Zn transporter, and the copper-transporting ATPase (ATF7A) are involved in the accumulation of $\mathrm{Zn}$ and $\mathrm{Cu}$ in the synapse, respectively. $\mathrm{Cu}^{2+}$ and $\mathrm{Zn}^{2+}$ may spill over to the neighboring synapses and modulate excitability, and are implicated in the maintenance of synaptic plasticity and memory formation.

\section{Vascular Dementia and Zinc}

Senile dementia is a serious problem for our rapidly aging society. It is characterized by profound memory loss and the inability to form new memories in older adults, and its prevalence increases with age. The number of patients in Japan, including those with a mild cognitive deficiency, is estimated to be more than 800 million.

Senile dementia is mainly divided into Alzheimer's disease (AD), vascular dementia (VD), and dementia with Lewy bodies (DLB). Both AD and DLB are characterized by the deposition of abnormally accumulated proteins: $\beta$-amyloid protein $(\mathrm{A} \beta \mathrm{P})$ in $\mathrm{AD}$ and $\alpha$-synuclein ( $\alpha$-Syn) in DLB. VD accounts for approximately one-third of senile dementia cases in Japan. VD is a degenerative cerebrovascular disease that is mainly caused by a series of strokes or ischemia [6]. Risk factors for VD include age, male sex, diabetes, and high blood pressure [30]. After transient global ischemia, the interruption of blood flow and its reperfusion cause the deprivation of oxygen and glucose and the production of ROS. Thereafter, abnormal neuronal excitation occurs in large parts of the brain with the excessive release of glutamate into the synaptic clefts. The excess glutamate causes 
over-stimulation of its receptors, and the successive entry of large quantities of calcium ions $\left(\mathrm{Ca}^{2+}\right)$ triggers the delayed death of vulnerable neurons, such as pyramidal neurons in the hippocampus, which is an area associated with learning, memory and language. Thus, the development of an infarct and the subsequent cognitive dysfunction characterize the pathogenesis of VD in elderly individuals. An epidemiological study reported the occurrence of dementia symptoms in about $30 \%$ of stroke patients within 3 years of the initial stroke [31].

Increasing evidence suggests that $\mathrm{Zn}$ has a causative role in neuronal injury after transient global ischemia, ultimately leading to $\mathrm{VD}$ [32]. As noted, $\mathrm{Zn}^{2+}$ co-accumulates with glutamate in the presynaptic vesicles and is co-released into the synaptic cleft under ischemic conditions. The concentration of $\mathrm{Zn}^{2+}$ is estimated to be up to $300 \mu \mathrm{M}$ [33]. Excess $\mathrm{Zn}^{2+}$ reportedly causes the apoptotic death of cultured neurons or neuroblastoma cells (PC12 cells) [34,35]. Koh et al. demonstrated that $\mathrm{Zn}^{2+}$ accumulates in apoptotic neurons in the hippocampus after ischemia [36]. "Zn translocation", namely the entry of Zn from presynaptic vesicles into the postsynaptic neurons, and the increase in intracellular $\mathrm{Zn}^{2+}$ levels $\left(\left[\mathrm{Zn}^{2+}\right]_{\mathrm{i}}\right)$, occurs in vulnerable neurons in the CA1 or CA3 regions of the hippocampus prior to the onset of delayed neuronal death following transient global ischemia, enhancing the appearance of the infarct [37]. There are three routes of $\mathrm{Zn}^{2+}$ entry into the cell: AMPAtype glutamate receptors, NMDA-type glutamate receptors, and the voltage-gated L-type $\mathrm{Ca}^{2+}$ channel (VGLC). Under normal conditions, most hippocampal neurons express AMPA receptors containing the subunit GluR2, which are poorly permeable to $\mathrm{Ca}^{2+}$ and $\mathrm{Zn}^{2+}$ [38]. However, after ischemia, an acute reduction in the expression of the GluR2 subunit occurs, and neurons express a specific type of AMPA receptor that has channels that are directly $\mathrm{Ca}^{2+}$-permeable (Ca-AMPA/kainate channels: Ca-A/K-R). The appearance of Ca-A/K-R channels causes an increased permeability for $\mathrm{Ca}^{2+}$ and $\mathrm{Zn}^{2+}$ and enhances their toxicity. Therefore, the expression of $\mathrm{Zn}^{2+}$-permeable Ca-A/K-R channels and the entry of $\mathrm{Ca}^{2+}$ and/or $\mathrm{Zn}^{2+}$ through these channels mediate delayed neuronal death after ischemia. Furthermore, the administration of calcium ethylenediaminetetraacetic acid (Ca EDTA), a membrane-impermeable $\mathrm{Zn}$ chelator, blocks the translocation of $\mathrm{Zn}$, protects hippocampal neurons after transient global ischemia, and reduces infarct volume [39]. Because Ca EDTA attenuates the ischemia-induced downregulation of the GluR2 gene, $\mathrm{Zn}$ is also implicated in the transcriptional regulation of $\mathrm{Ca}-\mathrm{A} / \mathrm{K}-\mathrm{R}$ channels. These results strongly suggest that Zn plays a key role in delayed neuronal death after transient global ischemia, a process that is potentially involved in the pathogenesis of VD.

\section{Copper Enhances Zinc-Induced Neurotoxicity}

An understanding of the molecular mechanism underlying $\mathrm{Zn}^{2+}$-induced neurodegeneration will advance the development of treatments for VD. We found that $\mathrm{Zn}$ causes the apoptotic death of GT1-7 cells (immortalized hypothalamic neurons) in a dose-dependent and time-dependent manner [40]. GT1-7 cells are much more sensitive to Zn and exhibited much lower viability after Zn exposure compared with other neuronal cells, such as PC-12 cells, primary cultured rat hippocampal neurons, and B-50 neuroblastoma cells [41]. The degenerated GT1-7 cells were terminal deoxynucleotidyl transferase-mediated biotinylated UTP nick-end labeling (TUNEL)-positive and exhibited DNA fragmentation. The GT1-7 cells, which were developed by genetical targeted tumorigenesis of mouse hypothalamic neurons, possess neuronal characteristics, such as the extension of neuritis, secretion of gonadotropin-releasing hormone $(\mathrm{GnRH})$, and expression of neuron-specific proteins or receptors, including microtubule-associated protein 2 (MAP2), tau protein, neurofilaments, synaptophysin, GABA receptors, dopamine receptors, and L-type $\mathrm{Ca}^{2+}$ channels [42]. Notably, the GT1-7 cells are not subject to glutamate toxicity [8] because they either lack or possess low levels of ionotropic glutamate receptors [43]. Because of these properties, we considered the GT1-7 cell line to be an excellent model system for investigating $\mathrm{Zn}^{2+}$-induced neurotoxicity. 
First, we examined the effects of treatment with various pharmacological agents prior to $\mathrm{Zn}^{2+}$ treatment of GT1-7 cells and found that neither antagonists nor agonists of excitatory neurotransmitters (D-APV, glutamate and CNQX) nor those of inhibitory neurotransmitters (bicuculline, muscimol, baclofen and GABA) influenced the viability of GT1-7 cells [44-47]. Thus, it is possible that glutamate receptors and/or GABA receptors are not involved in the Zn-induced neurodegenerative pathways. However, several compounds, including energy substrates (pyruvate, citrate), metal chelators (o-phenanthroline, deferoxamine), dipeptides (carnosine, anserine), and amino acids (histidine), attenuated the $\mathrm{Zn}^{2+}$-induced death of GT1-7 cells.

We examined the effects of other metal ions on $\mathrm{Zn}$-induced neurotoxicity and found that co-exposure with aluminum ions $\left(\mathrm{Al}^{3+}\right)$, gadolinium ions $\left(\mathrm{Gd}^{3+}\right)$, or $\mathrm{Ca}^{2+}$ attenuated the $\mathrm{Zn}^{2+}$-induced death of GT1-7 cells $[13,48]$. However, co-existence with $\mathrm{Cu}^{2+}$ or nickel ions $\left(\mathrm{Ni}^{2+}\right)$ remarkably exacerbated $\mathrm{Zn}$-induced neurotoxicity [9]. Although cells exposed to $\mathrm{Cu}^{2+}\left(\mathrm{CuCl}_{2}\right)$ alone $(0-80 \mu \mathrm{M})$ did not exhibit neurodegenerative changes after exposure for $24 \mathrm{~h}, 30 \mu \mathrm{M}$ of $\mathrm{Zn}^{2+}$ caused the loss of $39.0 \pm 1.0 \%$ of GT1-7 cells (Figure 2). Meanwhile, the co-exposure of $2.5 \mu \mathrm{M} \mathrm{Cu}$ with $30 \mu \mathrm{M} \mathrm{Zn}$ (molar ratio of $\mathrm{Cu}: \mathrm{Zn}=1: 12$ ) resulted in a $76.2 \pm 3.3 \%$ decrease in cell viability, and $10 \mu \mathrm{M} \mathrm{Cu}$ with $30 \mu \mathrm{M} \mathrm{Zn}$ (molar ratio of $\mathrm{Cu}: \mathrm{Zn}=1: 3$ ) resulted in a $93.8 \pm 2.3 \%$ decrease in cell viability. Although we applied $\mathrm{ZnCl}_{2}$ or $\mathrm{CuCl}_{2}$ in the culture media, it is plausible that these metals can bind in a labile manner to small compounds such as citrate or ATP. These results were contrary to our expectation that $\mathrm{Cu}^{2+}$ may compete with $\mathrm{Zn}^{2+}$-induced neurotoxicity. Therefore, we focused on the molecular mechanism of $\mathrm{Cu}^{2+}$-enhanced $\mathrm{Zn}^{2+}$-induced neurotoxicity $(\mathrm{Cu} / \mathrm{Zn}$ neurotoxicity).

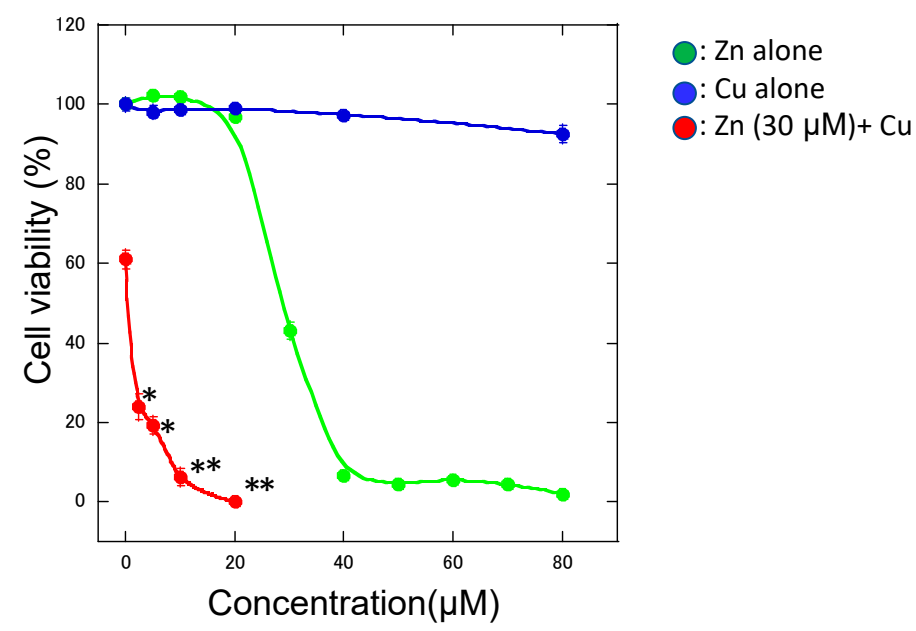

Figure 2. $\mathrm{Cu}^{2+}$-enhanced $\mathrm{Zn}^{2+}$-induced neurotoxicity. Various concentrations of $\mathrm{CuCl}_{2}$ alone (blue circle), $\mathrm{ZnCl}_{2}$ alone (green circle), and $\mathrm{CuCl}_{2}(0-20 \mu \mathrm{M})$ with $30 \mu \mathrm{M} \mathrm{ZnCl} 2$ (red circle) were administered to GT1-7 cells in serum-free culture media. After $24 \mathrm{~h}$, cell viability was determined using the CellTiter-Glo ${ }^{\circledR}$ assay. Data are presented as mean \pm S.E.M. ${ }^{*} p<0.05,{ }^{* *} p<0.01$ versus $30 \mu \mathrm{M} \mathrm{ZnCl}_{2}$ alone (Tukey's test).

\section{The Molecular Pathways of Copper-Enhanced Zinc-Induced Neurotoxicity}

Examination of the molecular pathways involved in the neurotoxicity induced by coexposure to $\mathrm{Cu} / \mathrm{Zn}$ may facilitate the development of drugs for the treatment/prevention of VD. Using DNA microarray analysis and real-time PCR (RT-PCR) techniques, we demonstrated that various genes, including metal-related genes ( $\mathrm{Zn}$ transporter 1 (ZnT-1), metallothionein 1 (MT1), and metallothionein 2 (MT2)), endoplasmic reticulum (ER)-stressrelated genes (CHOP, GADD34), signal-transduction-related genes, and $\mathrm{Ca}^{2+}$-signalingrelated genes $(A r c)$, were upregulated after exposure to $\mathrm{Zn}^{2+}$ alone $[46,47]$. Based on the DNA microarray analysis of GT1-7 cells exposed to $\mathrm{Cu}^{2+}$ and $\mathrm{Zn}^{2+}$, we found that several genes related to ER stress pathways and MAP kinase pathways were especially 
upregulated in $\mathrm{Cu} / \mathrm{Zn}$ conditions compared with $\mathrm{Zn}$ alone [9-12]. Herein, we focus on the five neurodegenerative pathways.

\subsection{ER Stress Pathway}

The ER stress pathway, which impairs ER function and leads to an accumulation of unfolded or misfolded proteins, is implicated in many neurodegenerative diseases, including AD, PD, and cerebral ischemia [49]. ER stress is mediated by three sensors at the ER membrane: PKR-like endoplasmic reticulum eIF2a kinase (PERK), inositol requiring 1 (IRE1), and activating transcription factor 6 (ATF6) [50]. In the PERK branch, activating transcription factor 4 (ATF4) induces $\mathrm{C} / \mathrm{EBP}$ homologous protein (CHOP), which triggers an intrinsic apoptotic pathway, such as caspase cascades [51], and thereafter $\mathrm{CHOP}$ induces GADD34 (protein phosphatase 1 regulatory subunit 15A).

We previously found that $\mathrm{Zn}^{2+}$ induces marked upregulation of endoplasmic reticulum (ER)-stress-related genes, especially CHOP and GADD34 in GT1-7 cells [47,48]. We demonstrated that genes related to the PERK branch (ATF4, CHOP and GADD34) were upregulated during $\mathrm{Cu} / \mathrm{Zn}$ neurotoxicity using RT-PCR analysis [9]. The induction of $\mathrm{CHOP}$ protein and the correlation with cell viability were observed by Western blotting analysis. Although $\mathrm{Zn}^{2+}$ alone induced these ER-stress-related genes, $\mathrm{Cu}^{2+}$ alone did not influence these genes. Therefore, it is possible that the ATF4-CHOP-GADD34 axis is responsible for the apoptotic death observed in $\mathrm{Cu} / \mathrm{Zn}$ neurotoxicity. We found that the ER stress pathway is also involved in $\mathrm{Ni}^{2+}$-enhanced $\mathrm{Zn}^{2+}$-induced neurotoxicity of GT1-7 cells [52].

\subsection{SAPK/JNK Pathway}

We also found that genes related to the MAP kinase (MAPK) signaling pathway were upregulated after co-exposure to $\mathrm{Cu}^{2+}$ and $\mathrm{Zn}^{2+}$. The MAPKs are serine/threonine protein kinases that mediate complex signal transduction based on various cellular processes, including proliferation, differentiation, migration, cell death/survival and environmental stress response [53]. There are four subfamilies: the extracellular signal-regulated kinases (ERK1/2), the c-Jun $\mathrm{NH}_{2}$-terminal kinases (JNK 1, 2 and 3), the p38 kinases, and the ERK5 (also known as big MAPK-1, BMK1) subfamilies. Among them, the SAPK/JNK signaling pathway plays an important role in apoptotic cell death, necroptosis, and autophagy [54]. The SAPK/JNK signaling pathway is activated by a variety of environmental stressors, such as oxidative stress, inflammatory cytokines and metals. Upon activation of this pathway by various stressors, MAPK kinase 4 (MKK4) or MKK7 phosphorylates and activates SAPK/JNK. Then, c-Jun and activating transcription factor 2 (ATF2), known major downstream factors of SAPK/JNK, are phosphorylated and activated by SAPK/JNK. Ultimately, phosphorylated forms of c-Jun and ATF2 induce downstream factors related to cell death and mitochondrial injury, leading to cell death.

Using RT-PCR and Western blotting, we found that the phosphorylated (i.e., active) forms of SAPK/JNK were increased by co-treatment of $\mathrm{Cu}^{2+}$ and $\mathrm{Zn}^{2+}$, but not by $\mathrm{Zn}^{2+}$ alone nor by $\mathrm{Cu}^{2+}$ alone [10]. We found that phospho-c-Jun and phospho-ATF2 were also induced by $\mathrm{Cu}^{2+}$ and $\mathrm{Zn}^{2+}$. Moreover, an inhibitor of the SAPK/JNK signaling pathway (SP600125) significantly suppressed the induction of $\mathrm{CHOP}$ by co-treatment of $\mathrm{Cu}^{2+}$ and $\mathrm{Zn}^{2+}$ and the activation of the SAPK/JNK signaling pathway and attenuated the neuronal cell death.

\subsection{Energy Production Pathway}

We have already demonstrated that pyruvate, an energy substrate, attenuated $\mathrm{Zn}^{2+}$ induced neurotoxicity [40]. Shelline and colleagues reported that $\mathrm{Zn}$ exposure decreased the levels of nicotinamide adenine dinucleotide $\left(\mathrm{NAD}^{+}\right)$and ATP in cultured cortical neurons, and that treatment with pyruvate restored the $\mathrm{NAD}^{+}$level $[55,56]$. The administration of pyruvate attenuated neuronal death after ischemia in vivo [57]. We found that pyruvate and citrate attenuated $\mathrm{Cu} / \mathrm{Zn}$ neurotoxicity [58]. Furthermore, the co-existence of pyruvate and 
citrate did not influence the intracellular concentrations of $\mathrm{Zn}^{2+}$ and $\mathrm{Cu}^{2+}$ of GT1-7 cells nor the elevations of MTs mRNA. Therefore, it is unlikely that pyruvate and citrate attenuated $\mathrm{Cu} / \mathrm{Zn}$ neurotoxicity by the chelation to $\mathrm{Cu}^{2+}$ and / or $\mathrm{Zn}^{2+}$. Therefore, it is possible that the mitochondrial energy production pathway is involved in $\mathrm{Cu} / \mathrm{Zn}$ neurotoxicity as well as $\mathrm{Zn}^{2+}$-induced neurotoxicity.

\subsection{Disruption of $\mathrm{Ca}^{2+}$ Homeostasis}

The upstream factors that underlie the $\mathrm{Cu} / \mathrm{Zn}$-induced ER stress pathway and the SAPK/JNK pathway are a matter of interest. Here, we focus on two possible upstream pathways: $\mathrm{Ca}^{2+}$ homeostasis and ROS production. Both pathways are known to regulate the ER stress pathway and the SAPK/JNK pathway. Notably, disrupted $\mathrm{Ca}^{2+}$ homeostasis is also reportedly involved in $\mathrm{Zn}^{2+}$-induced neuronal death. Kim et al. reported that $\mathrm{Zn}$ neurotoxicity in PC-12 cells was attenuated by an L-type $\mathrm{Ca}^{2+}$ channel blocker, nimodipine, and enhanced by the L-type $\mathrm{Ca}^{2+}$ channel activator S(-)-Bay K 8644 [35]. Additionally, Zn neurotoxicity was attenuated by aspirin, which prevents $\mathrm{Zn}^{2+}$ entry through voltage-gated $\mathrm{Ca}^{2+}$ channels (VGLCs) [59].

Using a high-resolution multi-site video imaging system with fura-2 as the cytosolic free calcium reporter fluorescent probe, we previously demonstrated that the exposure of $\mathrm{Zn}^{2+}$ caused an elevation in intracellular concentrations of $\mathrm{Ca}^{2+}\left(\left[\mathrm{Ca}^{2+}\right]_{\mathrm{i}}\right)$ in GT1-7 cells after 3-30 min of exposure [41]. The addition of $\mathrm{Ca}^{2+}, \mathrm{Al}^{3+}$ and $\mathrm{Gd}^{3+}$ attenuated the $\mathrm{Zn}^{2+}$ induced death of GT1-7 cells. It is widely known that $\mathrm{Gd}^{3+}$ is a blocker of VGLCs [60] and that $\mathrm{Al}^{3+}$ inhibits various types of $\mathrm{Ca}^{2+}$ channels [61]. We found that pretreatment with $\mathrm{Al}^{3+}$ significantly blocked the $\mathrm{Zn}$-induced $\left[\mathrm{Ca}^{2+}\right]_{i}$ elevations and attenuated the $\mathrm{Zn}^{2+}$ induced neurotoxicity of GT1-7 cells [41]. These results suggest that $\mathrm{Ca}^{2+}$ dyshomeostasis is involved in the mechanism of $\mathrm{Zn}$-induced neurotoxicity. It is plausible that the disruption of $\mathrm{Ca}^{2+}$ homeostasis is also involved in $\mathrm{Cu} / \mathrm{Zn}$ neurotoxicity.

\subsection{ROS Production}

It is widely known that oxidative stress is involved in various neurodegenerative diseases. ROS reportedly induce the ER stress pathway [62], the SAPK/JNK pathway [63], and numerous other adverse effects. As previously noted, an inhibitor of SAPK/JNK (SP600125) suppresses $\mathrm{Cu}^{2+} / \mathrm{Zn}^{2+}$-dependent increases in CHOP expression, suggesting that the ROSJNK-CHOP pathway is involved in $\mathrm{Cu} / \mathrm{Zn}$ neurotoxicity. The ROS-JNK-CHOP pathway is also implicated in other types of cell death, such as TNF-related apoptosis-inducing ligand (TRAIL)-induced apoptosis [64].

$\mathrm{Cu}$ is a redox-active metal that exists as oxidized $\mathrm{Cu}^{2+}$ and reduced $\mathrm{Cu}^{+}$, while $\mathrm{Zn}$ exists only as $\mathrm{Zn}^{2+}$ and is not directly implicated in the redox pathway. The addition of $\mathrm{Cu}^{2+}$ induced ROS production in GT1-7 cells, while $\mathrm{Zn}^{2+}$ alone did not produce ROS or influence $\mathrm{Cu}^{2+}$-induced ROS production in GT1-7 cells [10]. We examined the involvement of oxidative stress in activation of the SAPK/JNK signaling pathway and found that human serum albumin-thioredoxin fusion protein (HSA-Trx), an antioxidative protein, suppressed activation of the SAPK/JNK signaling pathway, inhibited ROS production, and attenuated $\mathrm{Cu} / \mathrm{Zn}$ neuronal death of GT1-7 cells [11]. Furthermore, selenomethionine (Se-Met), an endogenous selenium (Se)-containing amino acid, induced glutathione peroxidase and blocked ROS production [12]. Pretreatment with Se-Met significantly suppressed the induction of $\mathrm{CHOP}$ and attenuated $\mathrm{Cu} / \mathrm{Zn}$ neurotoxicity.

\section{Hypothetical Scheme Regarding $\mathrm{Cu} / \mathrm{Zn}$ Neurotoxicity}

On the basis of these findings, we established a hypothetical scheme regarding $\mathrm{Cu} / \mathrm{Zn}$ neurotoxicity and the implication of $\mathrm{Cu}$ and / or $\mathrm{Zn}$ in the pathogenesis of vascular dementia (Figure 3).

Under normal conditions, $\mathrm{Zn}^{2+}$ and/or $\mathrm{Cu}^{2+}$ are secreted into the synaptic cleft during neuronal excitation in a distinctive manner and modulate neuronal information processing. 
The co-existence of $\mathrm{Zn}^{2+}$ and $\mathrm{Cu}^{2+}$ in the same synapse does not often occur because the secreted $\mathrm{Zn}^{2+}$ and/or $\mathrm{Cu}^{2+}$ experience rapid re-uptake by $\mathrm{Zn}$ transporters or by CTR1.

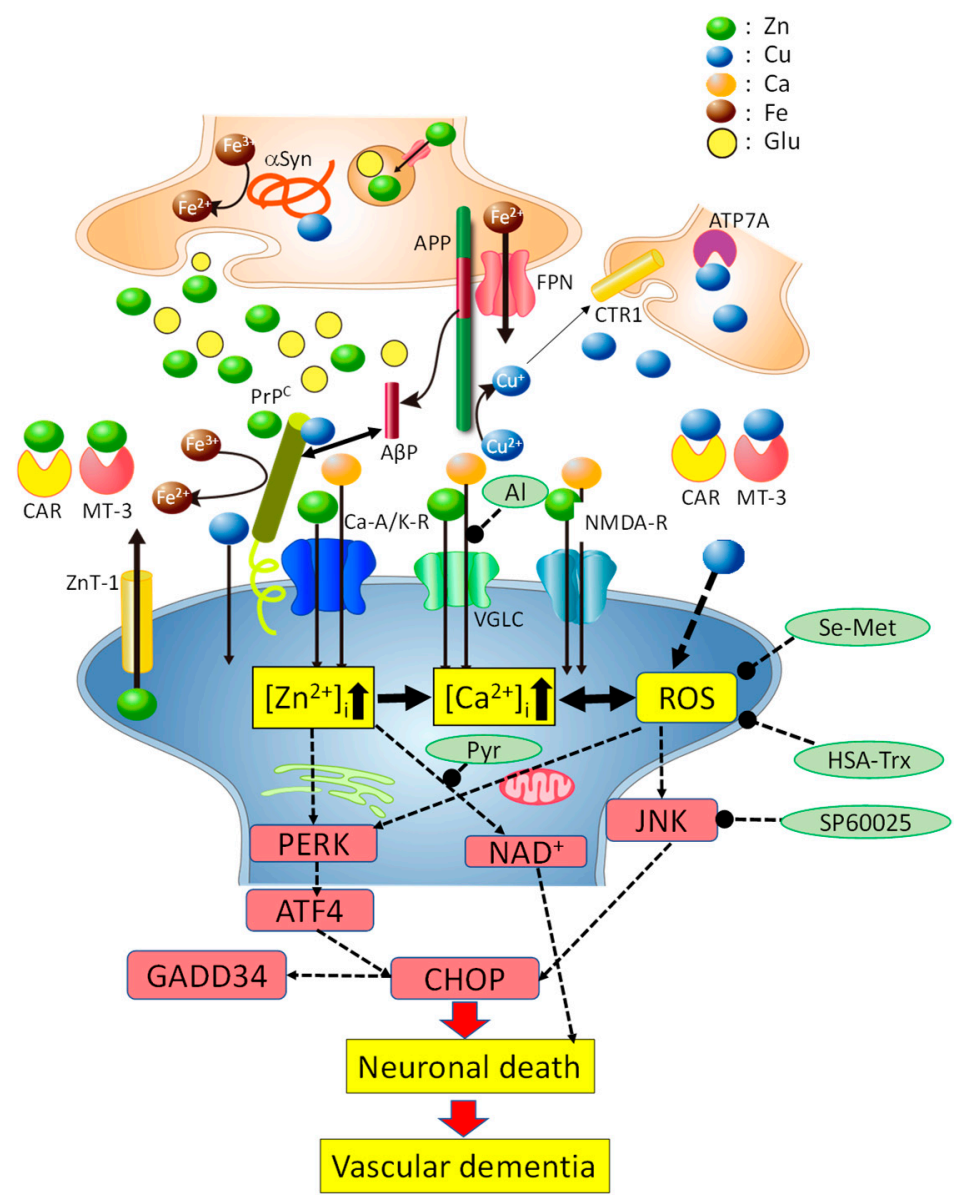

Figure 3. Hypothetical scheme regarding $\mathrm{Cu} / \mathrm{Zn}$ neurotoxicity. Under pathological conditions such as transient global ischemia, excess $\mathrm{Cu}^{2+}$ and $\mathrm{Zn}^{2+}$ co-exist in the synaptic cleft. The elevation in $\left[\mathrm{Zn}^{2+}\right]_{\mathrm{i}}$ and $\left[\mathrm{Ca}^{2+}\right]_{\mathrm{i}}$ triggers ER stress pathways, inhibits the energy production pathway in mitochondria, and induces neurodegeneration. The co-existence of $\mathrm{Cu}^{2+}$ with $\mathrm{Zn}^{2+}$ causes the production of ROS, upregulates the ER stress pathway and the SAPK/JNK pathway, and finally exacerbates neuronal death. Cu-binding proteins, including normal cellular prion protein $\left(\operatorname{PrP}^{\mathrm{C}}\right)$, amyloid precursor protein (APP), and $\alpha$-synuclein ( $\alpha$-Syn), are located in the synapse and regulate the levels of metals such as $\mathrm{Cu}, \mathrm{Zn}$ and Fe. Additionally, $\operatorname{PrP}^{\mathrm{C}}$ regulates $\mathrm{Zn}^{2+}$ levels as a $\mathrm{ZIP}$ $\mathrm{Zn}$ transporter analogue with the ZnT-1 Zn transporter, which is also localized to postsynaptic membranes. $\mathrm{PrP}^{\mathrm{C}}$ can provide $\mathrm{Cu}$ to $\mathrm{APP}$ or other $\mathrm{Cu}$-binding proteins in the synapse. APP is mainly localized to the presynaptic membrane. APP binds to $\mathrm{Cu}$ and/or $\mathrm{Zn}$ and can convert $\mathrm{Cu}^{2+}$ to $\mathrm{Cu}^{+}$. APP can provide $\mathrm{Cu}^{+}$to CTR1 or other $\mathrm{Cu}^{+}$-binding proteins. APP also regulates $\mathrm{Fe}^{2+}$ efflux from cells via ferroportin. $\alpha$-Syn is mainly localized to the presynaptic domain and binds $\mathrm{Cu}, \mathrm{Mn}$, and Fe. Both $\mathrm{PrP}^{\mathrm{C}}$ and $\alpha$-Syn have ferrireductase activity and provide bioavailable $\mathrm{Fe}^{2+}$ to enzymes at the pre- and post-synapse, respectively. Other metal-binding factors such as metallothionein 3 (MT-3) and carnosine (Car) are secreted into synaptic clefts and play critical roles in the maintenance of metal homeostasis. NMDA-R, NMDA-type glutamate receptor; $\mathrm{Ca}-\mathrm{A} / \mathrm{K}-\mathrm{R}, \mathrm{Ca}^{2+}$-permeable AMPA/kainate-type glutamate receptor; VGLC, voltage-gated L-type $\mathrm{Ca}^{2+}$ channel; FPN, ferroportin. The colored circles represent $\mathrm{Zn}, \mathrm{Cu}, \mathrm{Fe}, \mathrm{Ca}$ and glutamate.

However, under pathogenetic conditions such as transient global ischemia, long-term neuronal excitation occurs in major parts of the brain and, thereafter, $\mathrm{Zn}^{2+}$ and $\mathrm{Cu}^{2+}$ are released and abundantly co-localize in the same synaptic clefts. Excess $\mathrm{Zn}^{2+}$ induces a reduction in the expression of the GluR2 subunit, and the elevation in $\left[\mathrm{Zn}^{2+}\right]_{i}$ and $\left[\mathrm{Ca}^{2+}\right]_{i}$ 
occurs through Ca-A/K-Rs, NMDA-Rs and VGLCs. $\mathrm{Al}^{3+}$, a known $\mathrm{Ca}^{2+}$ channel blocker, blocks $\mathrm{Zn}^{2+}$-induced elevation of $\left[\mathrm{Ca}^{2+}\right]_{i}$ and attenuates $\mathrm{Zn}^{2+}$-induced neuronal death Thereafter, the elevation in $\left[\mathrm{Zn}^{2+}\right]_{\mathrm{i}}$ and $\left[\mathrm{Ca}^{2+}\right]_{\mathrm{i}}$ triggers the PERK branch of the ER stress pathway, induces CHOP, and finally causes neuronal death. The increase in $\left[\mathrm{Zn}^{2+}\right]_{\mathrm{i}}$ also inhibits $\mathrm{NAD}^{+}$in the mitochondrial energy production pathway and causes the depletion of ATP, which leads to neurodegeneration.

When $\mathrm{Cu}^{2+}$ and $\mathrm{Zn}^{2+}$ co-exist in the same synaptic cleft, $\mathrm{Cu}^{2+}$ produces $\mathrm{ROS}$, which subsequently induces the PERK pathway and the SAPK/JNK pathway. Thereafter, both pathways induce $\mathrm{CHOP}$ and ultimately exacerbate $\mathrm{Zn}^{2+}$-induced neuronal death. SP600125, an inhibitor of the SAPK/JNK pathway, inhibits these processes and attenuates $\mathrm{Cu} / \mathrm{Zn}$ neurotoxicity. Antioxidants such as HSA-Trx or Se-Met inhibit ROS production by $\mathrm{Cu}^{2+}$ and attenuate $\mathrm{Cu} / \mathrm{Zn}$ neuronal death. In conclusion, synaptic $\mathrm{Cu}^{2+}$ collaborates with $\mathrm{Zn}^{2+}$ in the same synapse and the co-existence of $\mathrm{Cu}^{2+}$ and $\mathrm{Zn}^{2+}$ triggers neuronal death after transient global ischemia, ultimately causing the pathogenesis of VD. This hypothesis can explain various aspects of $\mathrm{Cu} / \mathrm{Zn}$ neurotoxicity and the involvement of synaptic $\mathrm{Cu}^{2+}$ and $\mathrm{Zn}^{2+}$ in the pathogenesis of VD. Several epidemiological findings suggest that elevated serum $\mathrm{Cu}$ is a risk factor of stroke [65-67].

Considering the abundance of $\mathrm{Cu}^{2+}$ and $\mathrm{Zn}^{2+}$ in the synapse, regulatory factors of metal homeostasis may exist in the synapse and play critical roles in the pathogenesis of VD. Several Cu-binding proteins are reportedly localized in the synapse $[4,68]$. Normal cellular prion protein $\left(\mathrm{PrP}^{\mathrm{C}}\right)$ exists at postsynaptic membranes. $\operatorname{PrPC}^{\mathrm{C}}$ binds to $\mathrm{Cu}$ at the $\mathrm{N}$-terminal octarepeat domain and contributes to intracellular uptake of $\mathrm{Cu}$ [4]. $\mathrm{PrP}^{\mathrm{C}}$ acts as a ZIP Zn transporter analogue and regulates cellular $\mathrm{Zn}$ uptake combined with the AMPA receptor [69]. The $\mathrm{ZnT}-1 \mathrm{Zn}$ transporter is also localized to postsynaptic membranes binding with glutamate receptors [70]. Therefore, both $\mathrm{PrP}^{\mathrm{C}}$ and $\mathrm{ZnT}-1$ control $\mathrm{Zn}^{2+}$ levels at the synapse. $\operatorname{PrPC}^{\mathrm{C}}$ also possesses ferrireductase activity to convert $\mathrm{Fe}^{3+}$ and $\mathrm{Fe}^{2+}$ and is involved in cellular uptake of $\mathrm{Fe}^{2+}$ [71]. Amyloid precursor protein (APP) is localized in the presynaptic membranes and possesses $\mathrm{Cu}$ - and/or Zn-binding domains. APP can convert $\mathrm{Cu}^{2+}$ to $\mathrm{Cu}^{+}$and contributes to the cellular uptake of $\mathrm{Cu}$ [72]. APP is also implicated in $\mathrm{Fe}^{2+}$ efflux by binding with ferroportin [73]. $\alpha$-Syn is a Cu-binding protein present in the presynaptic domain. Cu enhanced the oligomerization of $\alpha$-Syn [74]. $\alpha$-Syn also possesses ferrireductase activity to convert $\mathrm{Fe}^{3+}$ and $\mathrm{Fe}^{2+}$ [75]. Interestingly, all these proteins are involved in the pathogenesis of neurodegenerative diseases [68]. $\operatorname{PrP}^{\mathrm{C}}$ and its conformational changes are central to the pathogenesis of prion diseases, including scrapie in sheep, bovine spongiform encephalopathy in cattle, and Creutzfeldt-Jakob disease (CJD) in humans. The accumulation of A $\beta P$, which is secreted from APP, is observed in AD brain. The oligomerization and the neurotoxicity of $\mathrm{A} \beta \mathrm{P}$ are central in $\mathrm{AD}$. The deposition of $\alpha$-Syn as Lewy bodies has been characterized in the brains of patients with DLB. These disease-related proteins (amyloidogenic proteins) can act to maintain the homeostasis of $\mathrm{Cu}, \mathrm{Zn}$ and $\mathrm{Fe}$, while these metals can in turn regulate the expressions and functions of the disease-related proteins. The mRNAs of APP, $\alpha$-Syn, and $\operatorname{PrP}^{C}$ possess an ironresponsive element and, therefore, their expressions are regulated by $\mathrm{Fe}$ [76]. $\mathrm{Cu}$ regulates the processing of APP [77] and the production and clearance of A $\beta P$ [78]. Considering that these disease-related proteins co-exist in the synaptic cleft, which is a small compartment filled with $\mathrm{Cu}^{2+}$ and /or $\mathrm{Zn}^{2+}$, it is possible that these proteins can interact with each other in the maintenance of these metals $[79,80]$. Nibaldo et al. demonstrated that Cu-binding domains of both APP and $\mathrm{PrP}^{\mathrm{C}}$ prevent neurotoxicity of $\mathrm{Cu}$ [81]. A $\beta$ Ps reportedly inhibit the binding of $\mathrm{Cu}^{2+}$ to $\mathrm{PrP}^{\mathrm{C}}$ [82]. $\mathrm{PrP}^{\mathrm{C}}$ contributes to $\mathrm{AD}$ pathogenesis as a toxic receptor of $\mathrm{A} \beta \mathrm{P}$ oligomers [83]. Moreover, recent studies have suggested the involvement of $\operatorname{PrP}^{\mathrm{C}}$ in ischemia-induced neurotoxicity $[84,85]$.

Metal-metal or metal-protein crosstalk is complex and delicate. Therefore, it is plausible that the disorder of these regulatory proteins and disrupting $\mathrm{Cu}$ and/or $\mathrm{Zn}$ homeostasis may trigger various neurodegenerative diseases, including $\mathrm{AD}$, prion disease, DLB and VD. 
There are other regulatory factors of metal homeostasis in the synapse. Metallothionein3 (MT-3) and carnosine ( $\beta$-alanyl histidine) are secreted from glial cells or from neurons to the synaptic cleft $[86,87]$. Carnosine is an endogenous dipeptide that possesses various neuroprotective functions, including anti-oxidant, anti-crosslinking, and anti-glycation functions [8,88]. Carnosine has the ability to chelate to $\mathrm{Zn}^{2+}$ and/or $\mathrm{Cu}^{2+}$ [88]. The complex of $\mathrm{Zn}$ and carnosine (Poraprezinc) is widely used for the treatment of gastric ulcers. We have previously demonstrated that carnosine attenuated $\mathrm{Zn}^{2+}$-induced neuronal death [47]. Administration of carnosine was effective in the animal model of ischemic stroke [89]. Dietary supplementation of carnosine and anserine was revealed to improve the cognitive decline and maintenance of memory in elderly people [90]. Based on our findings regarding carnosine, we obtained a patent about carnosine and related compounds as a possible strategy for the prevention and treatment of VD [91,92].

\section{Conclusions}

Our findings regarding the role of $\mathrm{Cu}$ in $\mathrm{Zn}$-induced neurotoxicity and ischemiainduced neuronal death clarify the role of $\mathrm{Cu}$ as a collaborator with $\mathrm{Zn}$ in the pathogenesis of vascular-type dementia. The role of $\mathrm{Cu}$ in the synapse may enhance our understanding of the pathogenesis of $\mathrm{VD}$ and other neurodegenerative diseases. Substances that attenuate $\mathrm{Cu} / \mathrm{Zn}$ neurotoxicity may lead to strategies for the prevention or treatment of VD. Further research that provides a more detailed analysis of $\mathrm{Cu} / \mathrm{Zn}$ neurotoxicity and preventive substances is necessary.

Author Contributions: Participated in research design: K.-i.T. and M.K.; Conducted experiments: K.-i.T., M.K. and M.K.-N.; Wrote or contributed to the writing of the manuscript: K.-i.T., M.K. and M.K.-N. All authors have read and agreed to the published version of the manuscript.

Funding: This work was partially supported by a Grant-in-Aid for Scientific Research from the Ministry of Education, Culture, Sports, Science and Technology of Japan (JSPS Kakennhi Grant numbers. JP18K06669 and JP17H03197).

Acknowledgments: This work was partially supported by a Grant-in-Aid for Scientific Research from the Ministry of Education, Culture, Sports, Science and Technology. We thank Kobayashi, N. for technical assistance.

Conflicts of Interest: The authors declare that there are no conflict of interest.

\section{Abbreviations}

$\begin{array}{ll}\text { AD } & \text { Alzheimer's disease } \\ \text { A } \beta \text { P } & \text { Alzheimer's } \beta \text {-amyloid protein } \\ \text { ATF7A } & \text { copper-transporting ATPase 7A } \\ \text { AMPA } & \alpha \text {-amino-3-hydroxy-5-methylisoxazole-4-propionic acid } \\ \text { CSF } & \text { cerebrospinal fluid } \\ \text { CHOP } & \text { CCAAT-enhancer-binding protein homologous protein } \\ \text { CJD } & \text { Creutzfeldt-Jakob disease } \\ \text { CTR1 } & \text { copper transporter 1 } \\ \text { D-APV } & \text { 2-amino-5-phosphonovalerate } \\ \text { DLB } & \text { dementia with Lewy bodies } \\ \text { DMT1 } & \text { divalent metal transporter 1 } \\ \text { ER } & \text { endoplasmic reticulum } \\ \text { GABA } & \gamma \text {-aminobutyric acid } \\ \text { GADD34 } & \text { growth-arrest and DNA-damage-inducible gene 34 } \\ \left.\text { [Ca }{ }^{2+}\right]_{i} & \text { intracellular calcium levels } \\ \text { NMDA } & N \text {-methyl-D-aspartate } \\ \text { NAC } & \text { non-amyloid component } \\ \text { PD } & \text { Parkinson's disease } \\ \text { PrP } & \text { prion protein } \\ \text { ROS } & \text { reactive oxygen species }\end{array}$


SAPK/JNK stress-activated protein kinases/c-Jun amino-terminal kinases

VD vascular dementia

VGCC voltage-gated $\mathrm{Ca}^{2+}$ channel

CSF cerebrospinal fluid

DMT1 divalent metal transporter-1

\section{References}

1. Scheiber, I.F.; Mercer, J.F.B.; Dringen, R. Metabolism and functions of copper in brain. Prog. Neurobiol. 2014, 116, 33-57.

2. Gromadzka, G.; Tarnacka, B.; Flaga, A.; Adamczyk, A. Copper dyshomeostasis in neurodegenerative diseases-therapeutic implications. Int. J. Mol. Sci. 2020, 21, 9259. [CrossRef] [PubMed]

3. Acevedo, K.; Masaldan, S.; Opazo, C.M.; Bush, A.I. Redox active metals in neurodegenerative diseases. J. Biol. Inorg. Chem. 2019, 24, 1141-1157. [CrossRef] [PubMed]

4. Kawahara, M.; Kato-Negishi, M.; Tanaka, K.-I. Neurometals in the Pathogenesis of Prion Diseases. Int. J. Mol. Sci. 2021, 22, 1267. [CrossRef] [PubMed]

5. Gil-Bea, F.J.; Aldanondo, G.; Lasa-Fernández, H.; de Munain, A.L.; Vallejo-Illarramendi, A. Insights into the mechanisms of copper dyshomeostasis in amyotrophic lateral sclerosis. Expert Rev. Mol. Med. 2017, 19, e7. [CrossRef]

6. Lee, J.M.; Grabb, M.C.; Zipfel, G.Z.; Choi, D.W. Brain tissue responses to ischemia. J. Clin. Investig. 2000, 106, 723-731. [CrossRef]

7. Pochwat, B.; Nowak, G.; Szewczyk, B. Relationship between Zinc $\left(\mathrm{Zn}^{2+}\right)$ and glutamate receptors in the processes underlying neurodegeneration. Neural Plast. 2015, 591563. [CrossRef] [PubMed]

8. Kawahara, M.; Sadakane, Y.; Mizuno, K.; Kato-Negishi, M.; Tanaka, K.-I. Carnosine as a possible drug for zinc-induced neurotoxicity and vascular dementia. Int. J. Mol. Sci. 2020, 21, 2570. [CrossRef]

9. Tanaka, K.-I.; Kawahara, M. Copper enhances zinc-induced neurotoxicity and the endoplasmic reticulum stress response in a neuronal model of vascular dementia. Front. Neurosci. 2017, 11, 58. [CrossRef]

10. Tanaka, K.-I.; Shimoda, M.; Kasai, M.; Ikeda, M.; Ishima, Y.; Kawahara, M. Involvement of SAPK/JNK signaling pathway in copper enhanced zinc-induced neuronal cell death. Toxicol. Sci. 2019, 169, 293-302. [CrossRef]

11. Tanaka, K.-I.; Shimoda, M.; Chuang, V.T.G.; Nishida, K.; Kawahara, M.; Ishida, T.; Otagiri, M.; Maruyama, T.; Ishima, Y. Thioredoxin-albumin fusion protein prevents copper enhanced zinc-induced neurotoxicity via its antioxidative activity. Int. J. Pharm. 2018, 535, 140-147. [CrossRef]

12. Nakano, Y.; Shimoda, M.; Okudomi, S.; Kawaraya, S.; Kawahara, M.; Tanaka, K.-I. Seleno-L-methionine suppresses copperenhanced zinc-induced neuronal cell death via induction of glutathione peroxidase. Metallomics 2020, 12, 1693-1701. [CrossRef] [PubMed]

13. Kodama, H.; Fujisawa, C.; Bhadhprasit, B. Inherited copper transport disorders: Biochemical mechanisms, diagnosis, and treatment. Curr. Drug Metab. 2012, 13, 237-250. [CrossRef] [PubMed]

14. Opazo, C.M.; Greenough, M.; Bush, A.I. Copper: From neurotransmission to neuroproteostasis. Front. Aging Neurosci. 2014, 6, 1-7. [CrossRef]

15. D'Ambrosi, N.; Rossi, L. Copper at synapse: Release, binding and modulation of neurotransmission. Neurochem. Int. 2015, 90, 36-45. [CrossRef] [PubMed]

16. Han, M.; Chang, J.; Kim, J. Loss of divalent metal transporter 1 function promotes brain copper accumulation and increases impulsivity. J. Neurochem. 2016, 138, 918-928. [CrossRef]

17. Meskini, R.E.; Kelli, J.; Crabtree, L.; Cline, L.B.; Mains, R.E.; Eipper, A.; Ronnett, G.V. ATP7A (Menkes protein) functions in axonal targeting and synaptogenesis. Mol. Cell. Neurosci. 2007, 34, 409-421. [CrossRef]

18. Frederickson, C.J.; Suh, S.W.; Silva, D.; Frederickson, C.J.; Thompson, R.B. Importance of zinc in the central nervous system: The zinc-containing neuron. J. Nutr. 2000, 130, 1471S-1483S. [CrossRef]

19. Takeda, A.; Tamano, H. The impact of synaptic $\mathrm{Zn}^{2+}$ dynamics on cognition and its decline. Int. J. Mol. Sci. 2017, 18, 2411. [CrossRef]

20. Ueno, S.; Tsukamoto, M.; Hirano, T.; Kikuchi, K.; Yamada, M.K.; Nishiyama, N.; Nagano, N.; Matsuki, N.; Ikegaya, Y. Mossy fiber $\mathrm{Zn}^{2+}$ spillover modulates heterosynaptic $N$-methyl-D-aspartate receptor activity in hippocampal CA3 circuits. J. Cell Biol. 2002, 158, 215-220. [CrossRef]

21. Huston, J.P.; Wagner, U.; Hasenöhrl, R.U. The tuberomammillary nucleus projections in the control of learning, memory and reinforcement processes: Evidence for an inhibitory role. Behav. Brain Res. 1997, 83, 97-105. [CrossRef]

22. Kardos, J.; Héja, L.; Simon, A.; Jablonkai, I.; Kovács, R.; Jemnitz, K. Copper signalling: Causes and consequences. Cell Commun. Signal. 2018, 16, 71. [CrossRef] [PubMed]

23. Hojyo, S.; Fukada, T. Roles of zinc signaling in the immune system. J. Immunol. Res. 2016, 6762343. [CrossRef] [PubMed]

24. Gybina, A.A.; Tkac, I.; Prohaska, J.R. Copper deficiency alters the neurochemical profile of developing rat brain. Nutr. Neurosci. 2009, 12, 114-122. [CrossRef] [PubMed]

25. Roos, P.M.; Vesterberg, O.; Syversen, T.; Flaten, T.P.; Nordberg, M. Metal concentrations in cerebrospinal fluid and blood plasma from patients with amyotrophic lateral sclerosis. Biol. Trace Elem. Res. 2013, 151, 159-170. [CrossRef] [PubMed]

26. Schikorski, T.; Stevens, C.F. Quantitative ultrastructural analysis of hippocampal excitatory synapses. J. Neurosci. 1997, 17, 5858-5867. [CrossRef] 
27. Vogt, K.; Mellor, J.; Tong, G.; Nicoll, R. The actions of synaptically released zinc at hippocampal mossy fiber synapses. Neuron 2000, 26, 187-196. [CrossRef]

28. Kardos, J.; Kovács, I.; Hajós, F.; Kálmán, N.; Simonyi, M. Nerve endings from rat brain tissue release copper upon depolarization. A possible role in regulating neuronal excitability. Neurosci. Lett. 1989, 103, 139-144. [CrossRef]

29. Hopt, A.; Korte, S.; Fink, H.; Panne, U.; Niessner, R.; Jahn, R.; Herms, J. Methods for studying synaptosomal copper release. J. Neurosci. Methods 2003, 128, 159-172. [CrossRef]

30. Román, G.C. Vascular dementia prevention: A risk factor analysis. Cerebrovasc. Dis. 2005, 20, 91-100. [CrossRef]

31. De Haan, E.H.; Nys, G.M.; Van Zandvoort, M.J. Cognitive function following stroke and vascular cognitive impairment. Curr. Opin. Neurol. 2006, 19, 559-564.

32. Weiss, J.H.; Sensi, S.L.; Koh, J.Y. Zn ${ }^{2+}$ : A novel ionic mediator of neural injury in brain disease. Trends Pharmacol. Sci. 2000, 21, 395-401. [CrossRef]

33. Frederickson, C.J.; Hernandez, M.D.; Goik, S.A.; Morton, J.D.; McGinty, J.F. Loss of zinc staining from hippocampal mossy fibers during kainic acid induced seizures: A histofluorescence study. Brain Res. 1988, 446, 383-386.

34. Koh, J.Y.; Choi, D.W. Zinc toxicity of cultured cortical neurons: Involvement of N-methyl-D-asparatate receptors. Neuroscience 1994, 4, 1049-1057. [CrossRef]

35. Kim, A.H. L-type $\mathrm{Ca}^{2+}$ channel-mediated $\mathrm{Zn}^{2+}$ toxicity and modulation by ZnT-1 in PC12 cells. Brain Res. 2000, 886, 99-107. [CrossRef]

36. Koh, J.Y.; Suh, S.W.; Gwag, B.J.; He, Y.Y.; Hsu, C.Y.; Choi, D.W. The role of zinc in selective neuronal death after transient global cerebral ischemia. Science 1996, 272, 1013-1016. [CrossRef] [PubMed]

37. Sensi, S.L.; Canzoniero, L.M.; Yu, S.P.; Ying, H.S.; Koh, J.Y.; Kerchner, G.A.; Choi, D.W. Measurement of intracellular free zinc in living cortical neurons: Routes of entry. J. Neurosci. 1997, 17, 9554-9564.

38. Pellegrini-Giampietro, D.E.; Gorter, G.A.; Bennett, M.V.; Zukin, R.S. The GluR2 (GluR-B) hypothesis: Ca ${ }^{2+}$-permeable AMPA receptors in neurological disorders. Trends Neurosci. 1997, 20, 464-470.

39. Calderone, A.; Jover, T.; Mashiko, T.; Noh, K.; Tanaka, H.; Bennett, M.V.L.; Zukin, R.S. Late calcium EDTA rescues hippocampal CA1 neurons from global ischemia-induced death. J. Neurosci. 2004, 24, 9903-9913.

40. Kawahara, M.; Kato-Negishi, M.; Kuroda, Y. Pyruvate blocks zinc-induced neurotoxicity in immortalized hypothalamic neurons. Cell. Mol. Neurobiol. 2002, 22, 87-93. [CrossRef]

41. Koyama, H.; Konoha, K.; Sadakane, Y.; Ohkawara, S.; Kawahara, M. Zinc neurotoxicity and the pathogenesis of vascular-type dementia: Involvement of calcium dyshomeostasis and carnosine. J. Clin. Toxicol. 2011, 3. [CrossRef]

42. Mellon, P.L.; Windle, J.J.; Goldsmith, P.C.; Padula, C.A.; Roberts, J.L.; Weiner, R.I. Immortalization of hypothalamic GnRH neurons by genetically targeted tumorigenesis. Neuron 1990, 5, 1-10. [CrossRef]

43. Mahesh, V.B.; Zamorano, P.; De Sevilla, L.; Lewis, D.; Brann, D.W. Characterization of ionotropic glutamate receptors in rat hypothalamus, pituitary and immortalized gonadotropin-releasing hormone (GnRH) neurons (GT1-7 cells). Neuroendocrinology 1999, 69, 397-407. [CrossRef]

44. Kawahara, M.; Kato-Negishi, M.; Hosoda, R.; Kuroda, Y. Characterization of zinc-induced apoptosis of GT1-7 cells. Biomed. Res. Trace Elem. 2002, 13, 280-281.

45. Kawahara, M.; Konoha, K.; Sadakane, Y. Neurotoxicity of zinc: The involvement of calcium homeostasis and carnosine. Biomed. Res. Trace Elem. 2007, 18, 26-34.

46. Kawahara, M.; Sadakane, Y.; Koyama, H.; Konoha, K.; Ohkawara, S. D-histidine and L-histidine attenuate zinc-induced neuronal death in GT1-7 cells. Metallomics 2013, 5, 453-460. [CrossRef]

47. Mizuno, D.; Konoha-Mizuno, D.; Mori, M.; Sadakane, Y.; Koyama, H.; Ohkawara, S.; Kawahara, M. Protective activity of carnosine and anserine against zinc-induced neurotoxicity: A possible treatment for vascular dementia. Metallomics 2015, 7, 1233-1239. [CrossRef] [PubMed]

48. Konoha, K.; Sadakane, Y.; Kawahara, M. Effects of gadolinium and other metal on the neurotoxicity of immortalized hypothalamic neurons induced by zinc. Biomed. Res. Trace Elem. 2004, 15, 275-277.

49. Koksal, A.R.; Verne, G.N.; Zhou, Q. Endoplasmic reticulum stress in biological processing and disease. J. Investig. Med. 2021, 69, 309-315. [CrossRef]

50. Sano, R.; Reed, J.C. ER stress-induced cell death mechanisms. Biochim. Biophys. Acta BBA Mol. Cell Res. 2013, 1833, 3460-3470. [CrossRef]

51. Hu, H.; Tian, M.; Ding, C.; Yu, S. The C/EBP homologous protein (CHOP) transcription factor functions in endoplasmic reticulum stress-induced apoptosis and microbial infection. Front. Immunol. 2019, 9, 3083. [CrossRef]

52. Tanaka, K.-I.; Kasai, M.; Shimoda, M.; Shimizu, A.; Kubota, M.; Kawahara, M. Nickel enhances zinc-induced neuronal cell death by priming the endoplasmic reticulum stress response. Oxid. Med. Cell. Longev. 2019, 2019, 9693726. [CrossRef]

53. Kyosseva, S.V. Mitogen-activated protein kinase signaling. Int. Rev. Neurobiol. 2004, 59, 201-220. [PubMed]

54. Dhanasekaran, D.N.; Reddy, E.P. JNK-signaling: A multiplexing hub in programmed cell death. Genes Cancer 2017, 8, 682-694. [CrossRef] [PubMed]

55. Sheline, C.T.; Behrens, M.M.; Choi, D.W. Zinc-induced cortical neuronal death: Contribution of energy failure attributable to loss of $\mathrm{NAD}(+)$ and inhibition of glycolysis. J. Neurosci. 2000, 20, 3139-3154. [CrossRef] [PubMed] 
56. Cai, A.L.; Zipfel, G.J.; Sheline, C.T. Zinc neurotoxicity is dependent on intracellular NAD levels and the sirtuin pathway. Eur. J. Neurosci. 2006, 24, 2169-2176. [CrossRef]

57. Lee, J.Y.; Kim, Y.H.; Koh, J.Y. Protection by pyruvate against transient forebrain ischemia in rats. J. Neurosci. $2001,21, \mathrm{RC} 171$. [CrossRef]

58. Tanaka, K.-I.; Shimoda, M.; Kawahara, M. Pyruvic acid prevents $\mathrm{Cu}^{2+} / \mathrm{Zn}^{2+}$-induced neurotoxicity by suppressing mitochondrial injury. Biochem. Biophys. Res. Commun. 2018, 495, 1335-1341. [CrossRef]

59. Kim, E.Y.; Chang, S.Y.; Chung, J.M.; Ryu, B.R.; Joo, C.K.; Moon, H.S.; Kang, K.; Yoon, S.H.; Han, P.L.; Gwag, B.J. Attenuation of $\mathrm{Zn}^{2+}$ neurotoxicity by aspirin: Role of N-type $\mathrm{Ca}^{2+}$ channel and the carboxyl acid group. Neurobiol. Dis. 2001, 8, 774-783.

60. Gulati, P.; Muthuraman, A.; Jaggi, A.S.; Singh, N. Neuroprotective effect of gadolinium: A stretch-activated calcium channel blocker in mouse model of ischemia-reperfusion injury. Naunyn Schmiedeberg's Arch. Pharmacol. 2013, 386, 255-264. [CrossRef]

61. Platt, B.; Büsselberg, D. Combined actions of $\mathrm{Pb}^{2+}, \mathrm{Zn}^{2+}$, and $\mathrm{Al}^{3+}$ on voltage-activated calcium channel currents. Cell. Mol. Neurobiol. 1994, 14, 831-840. [CrossRef]

62. Konno, T.; Melo, E.P.; Chambers, J.E.; Avezov, E. Intracellular sources of ROS $/ \mathrm{H}_{2} \mathrm{O}_{2}$ in health and neurodegeneration: Spotlight on endoplasmic reticulum. Cells 2021, 10, 233. [CrossRef]

63. Dent, P.; Yacoub, A.; Contessa, J.; Caron, R.; Amorino, G.; Valerie, K.; Hagan, M.P.; Grant, S.; Schmidt-Ullrich, R. Stress and radiation-induced activation of multiple intracellular signaling pathways. Radiat. Res. 2003, 159, 283-300. [CrossRef]

64. Chang, C.C.; Kuan, C.P.; Lin, J.Y.; Lai, J.Y.; Ho, T.F. Tanshinone IIA facilitates TRAIL sensitization by up-regulating DR5 through the ROS-JNK-CHOP signaling axis in human ovarian carcinoma cell lines. Chem. Res. Toxicol. 2015, 28, 1574-1583. [CrossRef] [PubMed]

65. Xu, J.; Xu, G.; Fang, J. Association between serum copper and stroke risk factors in adults: Evidence from the National Health and Nutrition Examination Survey, 2011-2016. Biol. Trace Elem. Res. 2021. [CrossRef]

66. Hu, L.; Bi, C.; Lin, T.; Liu, L.; Song, Y.; Wang, P.; Wang, B.; Fang, C.; Ma, H.; Huang, X.; et al. Association between plasma copper levels and first stroke: A community-based nested case-control study. Nutr. Neurosci. 2021, 1-10. [CrossRef] [PubMed]

67. Zhang, M.; Li, W.; Wang, Y.; Wang, T.; Ma, M.; Tian, C. Association between the change of serum copper and ischemic stroke: A systematic review and meta-analysis. J. Mol. Neurosci. 2020, 70, 475-480. [CrossRef]

68. Kawahara, M.; Kato-Negishi, M.; Tanaka, K.-I. Amyloids: Regulators of metal homeostasis in the synapse. Molecules 2020, 25, 1441. [CrossRef]

69. Watt, N.T.; Griffiths, H.H.; Hooper, N.M. Neuronal zinc regulation and the prion protein. Prion 2013, 7, 203-208. [CrossRef]

70. Mellone, M.; Pelucchi, S.; Alberti, L.; Genazzani, A.A.; Luca, M.D.; Gardoni, F. Zinc transporter-1: A novel NMDA receptorbinding protein at the postsynaptic density. J. Neurochem. 2015, 132, 159-168. [CrossRef]

71. Singh, A.; Haldar, S.; Horback, K.; Tom, C.; Zhou, L.; Meyerson, H.; Singh, N. Prion protein regulates iron transport by functioning as a ferrireductase. J. Alzheimer's Dis. 2013, 35, 541-552. [CrossRef]

72. Multhaup, G.; Schlicksupp, A.; Hesse, L.; Beher, D.; Ruppert, T.; Masters, C.L.; Beyreuther, K. The amyloid precursor protein of Alzheimer's disease in the reduction of copper(II) to copper(I). Science 1996, 271, 1406-1409. [CrossRef]

73. Wong, B.X.; Tsatsanis, A.; Lim, L.Q.; Adlard, P.A.; Bush, A.I.; Duce, J.A. $\beta$-Amyloid precursor protein does not possess ferroxidase activity but does stabilize the cell surface ferrous iron exporter ferroportin. PLoS ONE 2014, 9, e114174. [CrossRef] [PubMed]

74. Moons, R.; Konijnenberg, A.; Mensch, C.; Van Elzen, R.; Johannessen, C.; Maudsley, S.; Lambeir, A.-M.; Sobott, F. Metal ions shape $\alpha$-synuclein. Sci. Rep. 2020, 10, 16293. [CrossRef] [PubMed]

75. Davies, P.; Moualla, D.; Brown, D.R. Alpha-synuclein is a cellular ferrireductase. PLoS ONE 2011, 6, e15814. [CrossRef]

76. Rogers, J.T.; Cahill, C.M. Iron-responsive-like elements and neurodegenerative ferroptosis. Learn. Mem. 2020, 27, 395-413. [CrossRef] [PubMed]

77. Hou, P.; Liu, G.; Zhao, Y.; Shi, Z.; Zheng, Q.; Bu, G.; Xu, H.; Zhang, Y. Role of copper and the copper-related protein CUTA in mediating APP processing and A $\beta$ generation. Neurobiol. Aging 2015, 36, 1310-1315. [CrossRef]

78. Singh, I.; Sagare, A.P.; Coma, M.; Perlmutter, D.; Gelein, R.; Bell, R.D.; Deane, R.J.; Zhong, E.; Parisi, M.; Ciszewski, J.; et al. Low levels of copper disrupt brain amyloid- $\beta$ homeostasis by altering its production and clearance. Proc. Natl. Acad. Sci. USA 2013, 110, 14771-14776. [CrossRef] [PubMed]

79. Inestrosa, N.C.; Cerpa, W.; Varela-Nallar, L. Copper brain homeostasis: Role of amyloid precursor protein and prion protein. IUBMB Life 2005, 57, 645-650. [CrossRef]

80. You, H.; Tsutsui, S.; Hameed, S.; Kannanayakal, T.J.; Chen, L.; Xia, P.; Engbers, J.D.T.; Lipton, S.A.; Stys, P.K.; Zamponi, G.W. A $\beta$ neurotoxicity depends on interactions between copper ions, prion protein, and N-methyl-D-aspartate receptors. Proc. Natl. Acad. Sci. USA 2012, 109, 1737-1742. [CrossRef]

81. Posadas, Y.; Parra-Ojeda, L.; Perez-Cruz, C.; Quintanar, L. Amyloid $\beta$ perturbs $\mathrm{Cu}(\mathrm{II})$ binding to the prion protein in a site-specific manner: Insights into its potential neurotoxic mechanisms. Inorg. Chem. 2021. [CrossRef]

82. Zhang, Y.; Zhao, Y.; Zhang, L.; Yu, W.; Wang, Y.; Chang, W. Cellular prion protein as a receptor of toxic amyloid- $\beta 42$ oligomers is important for Alzheimer's disease. Front. Cell. Neurosci. 2019, 13, 339. [CrossRef] [PubMed]

83. Puig, B.; Yang, D.; Brenna, S.; Altmeppen, H.C.; Magnus, T. Show me your friends and I tell you who you are: The many facets of prion protein in stroke. Cells 2020, 9, 1609. [CrossRef]

84. Black, S.A.G.; Stys, P.K.; Zamponi, G.W.; Tsutsui, S. Cellular prion protein and NMDA receptor modulation: Protecting against excitotoxicity. Front. Cell Dev. Biol. 2014, 2, 45. [CrossRef] 
85. Koh, J.Y.; Lee, S.J. Metallothionein-3 as a multifunctional player in the control of cellular processes and diseases. Mol. Brain 2020, 13, 116. [CrossRef] [PubMed]

86. Berezhnoy, D.S.; Stvolinsky, S.L.; Lopachev, A.V.; Devyatov, A.A.; Lopacheva, O.M.; Kulikova, O.I.; Abaimov, D.A.; Fedorova, T.N. Carnosine as an effective neuroprotector in brain pathology and potential neuromodulator in normal conditions. Amino Acids 2019, 51, 139-150. [CrossRef] [PubMed]

87. Boldyrev, A.A.; Aldini, G.; Derave, W. Physiology and pathophysiology of carnosine. Physiol. Rev. 2013, 93, 1803-1845. [CrossRef] [PubMed]

88. Trombley, P.Q.; Horning, M.S.; Blakemore, L.J. Interactions between carnosine and zinc and copper: Implications for neuromodulation and neuroprotection. Biochemistry 2000, 65, 807-816. [PubMed]

89. Davis, C.K.; Laud, P.J.; Bahor, Z.; Rajanikant, G.K.; Majid, A. Systematic review and stratified meta-analysis of the efficacy of carnosine in animal models of ischemic stroke. J. Cereb. Blood Flow Metab. 2016, 36, 1686-1694. [CrossRef] [PubMed]

90. Caruso, G.; Godos, J.; Castellano, S.; Micek, A.; Murabito, P.; Galvano, F.; Ferri, R.; Grosso, G.; Caraci, F. The Therapeutic Potential of Carnosine/Anserine Supplementation against Cognitive Decline: A Systematic Review with Meta-Analysis. Biomedicines 2021, 9, 253. [CrossRef]

91. Kawahara, M.; Konoha, K.; Nagata, T.; Sadakane, Y. Drugs for Prevention or Treatment of Vascular Dementia. JP Patent 5,382,633, 11 October 2013.

92. Kawahara, M.; Konoha, K.; Nagata, T.; Sadakane, Y. Drugs for Prevention or Treatment of Vascular Dementia. JP Patent 5,294,194, 21 June 2013. 